\title{
Lithocarpus orbicarpus (Fagaceae), a new species of Stone Oak from Phang Nga province, Thailand
}

\author{
Joeri S. Strijk', Sukontip Sirimongkol², Sukid Rueangruea², \\ Nikom Ritphet ${ }^{2}$, Voradol Chamchumroon ${ }^{2}$
}

\begin{abstract}
I Ecological Evolution Group, Key Laboratory of Tropical Forest Ecology, Xishuangbanna Tropical Botanical Garden, Chinese Academy of Sciences, Menglun, Mengla, Yunnan, 666303, PR China 2 Forest Herbarium (BKF), Department of National Parks, Wildlife and Plant Conservation, 61 Phahonyothin Rd., Chatuchak, Bangkok 10900, Thailand
\end{abstract}

Corresponding author: Joeri S. Strijk (joeristrijk@xtbg.org.cn)

Academic editor: H. Schaefer | Received 14 October 2013 | Accepted 2 February 2014 | Published 11 February 2014

Citation: Strijk JS, Sirimongkol S, Rueangruea S, Ritphet N, ChamchumroonV (2013) Lithocarpus orbicarpus (Fagaceae), a new species of Stone Oak from Phang Nga province, Thailand. PhytoKeys 34: 33-45. doi: 10.3897/phytokeys.34.6429

\begin{abstract}
A new species is described, Lithocarpus orbicarpus Strijk, collected from Ton Pariwat Wildlife Sanctuary, Mueang district, Phang Nga Province in the Peninsular Floristic Region of Thailand. We provide the first technical illustrations and colour photographs of the new species, as well as a description of its conservation status and the collecting locality. The species can be easily distinguished by its unique orbicular acorns, each covered with a dense pattern of irregularly placed scales, which completely conceal the nut, except for a tiny apical pore, and which are arranged in a dense cluster on an erect woody spike. We also provide an amendment to the existing diagnostic key to Lithocarpus, and discuss important differences with morphologically similar species found in Thailand and the surrounding region.
\end{abstract}

\section{Keywords}

Lithocarpus orbicarpus, new species, Stone Oaks, Fagaceae, Thailand, Ton Pariwat Wildlife Sanctuary

\section{Introduction}

Lithocarpus Blume is the second largest genus within Fagaceae, with over 300 species described (Camus 1948, 1954; Phengklai 2008; Soepadmo 1972; Wu et al. 1999). Members of the genus, commonly called Stone Oaks, can be found in (sub-) 
tropical broad-leaved evergreen forests near sea level to mixed forests at altitudes of over $3200 \mathrm{~m}$. The geographic distribution of Lithocarpus roughly covers southern and south-eastern Asia from eastern India to southern Japan, to the Philippines and southward to New Guinea. Lithocarpus densiflorus (Hook. \& Arn.) Rehder, the only North American member of the genus was recently moved to a new monotypic genus (Manos et al. 2008). All species within Lithocarpus are trees, ranging from small understory elements, to very large emergent trees. Many species have a geographically wide distribution and in some locations may constitute the main canopy forming elements together with other Fagaceae (Lithocarpus, Quercus, Castanopsis), Lauraceae and Theaceae. Leaves are simple, entire, rarely serrate, generally glabrous and mostly spirally arranged. Male and female flowers are white to pale whitish-yellow. Genders can be either on separate inflorescences, on the same inflorescence mixed throughout, or with female flowers below and male flowers terminal, arranged with dense indumentum on erect spikes. Male flowers are solitary or in clusters of three or more, with the perianth campanulate or cup-shaped, usually 6-lobed, partially united; stamens generally 12 . Female flowers solitary or in clusters of three, perianth like male flowers but smaller; 12 staminodes; 3(-4) styles (Camus 1948, 1954; Phengklai 2008).

Previous studies and the most recent treatment for Thailand have recovered 57 species of Lithocarpus (Barnett 1940; Phengklai 2004, 2008). During fieldwork in remote Ton Pariwat Wildlife Sanctuary, carried out as part of ongoing research on the genomics, systematics, biogeography and evolution of Asian Fagaceae, we made collections of an individual tree with unique features that could not be matched with any previously described taxa in Fagaceae. After careful examination of herbaria and literature, comparison of other specimens collected during the fieldwork and consultation of specialists on the regional flora, we report this collection here as a new species, placed within the genus Lithocarpus.

\section{Taxonomy}

Lithocarpus orbicarpus Strijk, sp. nov. urn:lsid:ipni.org:names:77135982-1 http://species-id.net/wiki/Lithocarpus_orbicarpus Fig. 1, 2

Type. THAILAND, Ton Pariwat Wildlife Sanctuary, Mueang district, Phang Nga Province, $8^{\circ} 37^{\prime} 25^{\prime \prime N}$; 983' $14 " E$; alt. 455 m, 16 July 2013, Chamchumroon et al. 5823 (Holotype: BKF; Isotypes: E, K, L, SING).

Diagnosis. Lithocarpus orbicarpus is a small-medium sized tree. It differs from similar species by its unique orbicular acorns, each covered with a dense pattern of irregularly placed scales, which completely conceal the nut, except for a tiny apical pore, and which are arranged in a dense cluster on an erect woody spike. Unique for Thai species of Lithocarpus, almost the entire surface of the round nut is covered with scar area (re- 
ceptacle tissue), leaving only the topmost part of the nut covered with a thin vestigial exocarp layer. Pending discovery of additional individuals, the species appears to be locally restricted to low-mid-elevation forests in the peninsular region of Thailand.

Description. Small-medium sized tree, up to $15 \mathrm{~m}$ tall. Bark smooth to slightly rough grey-green, with superficial horizontal lines. Sapwood white to yellow, with inner bark ridges forming light brown longitudinal slits in sapwood surface. Branches dark brown to grey brown, mostly glabrous, densely lenticellate; young twigs, leaf buds and old fruits with short, soft (occasionally long) gray indumentum. Leaf buds tiny and terminal buds solitary. Leaves simple; lamina elliptic to oblanceolate with (strongly) acuminate tip, $11.0-22.3 \times 4.4-7.1 \mathrm{~cm}$. Margin entire. Leaves often with slightly asymmetric lamina. Leaf apex acuminate to strongly acuminate, leaf base cuneate to slightly attenuate. Both surfaces generally glabrous except emerging leaf buds, terminal shoots and young leaves, which have soft grey indumentum. Young leaves light green, but turning dark green above and glaucous below when older. Venation. Pinnately veined; secondary venation discretely anastomosing near the leaf margin. Pairs of secondary veins 9-13, slightly raised and clearly visible on underside of leaf. Peduncles carrying fruits $5-11 \mathrm{~cm}$ long, up to $1 \mathrm{~cm}$ thick at the base, glabrescent, grey-brown and densely lenticellate. Male and female inflorescences not seen. Infructescence a woody spike, terminal, up to $15-21 \mathrm{~cm}$ long. Fruits sessile on thick woody peduncle, closely pressed against each other, but walls of individual units not fused. Number of fruits per infructescence very variable, ranging from 9-20 units. Acorn. Orbicular, globose, $2.7-3.4$ by $2.9-3.5 \mathrm{~cm}$ (including cupule) and covered with glabrous, semi-concentric interlocking ridges when young, which transform over time into ridges with irregularly placed scales. Cupule nearly completely enclosing the nut, indehiscent, but showing small cracks when mature; fruit wall up to $4-6 \mathrm{~mm}$ thick, apical pore very small, 1-4 mm wide, exposing the persistent punctiform styles (3) and a tiny fraction of vestigial exocarp. Young cupule walls light green, ridges light to dark brown. Old cupule walls turning light brown to yellow-brown and pubescent with short (occasionally long), greyish-yellow indumentum. Nut 1 in each cupule, ball shaped, globose, 2.4-2.9 by $2.6-3.0 \mathrm{~cm}$. Up to $95 \%$ of surface area of the nut made up of scar area (receptacle tissue), upper $5 \%$ of surface area of the nut slightly raised and made up of vestigial exocarp layer. Nut scar pale yellow-whitish, tiny exocarp layer light brown. Scar area covered with deep groves and red-brown to purplish vein-like lines, stretching down to the base of the nut. Up to 5/6 of the scar area of the young nut (from the base upward) covered with dotted pattern of small depressions. Cotyledons black when dried.

Flowering and fruiting. Flowering unknown, but thought to be around November-January. Infructescences on the ground in July, fruiting commencing possibly as early as April-May.

Distribution. This species is only known from Thailand, and has not been recorded outside Ton Pariwat Wildlife Sanctuary, Mueang district, Phang Nga Province. During our field survey, we found only one individual tree, located on a gentle sloping section of closed dense forest. Additional survey work will have to be undertaken to determine the actual population size of this species within the wildlife sanctuary. 


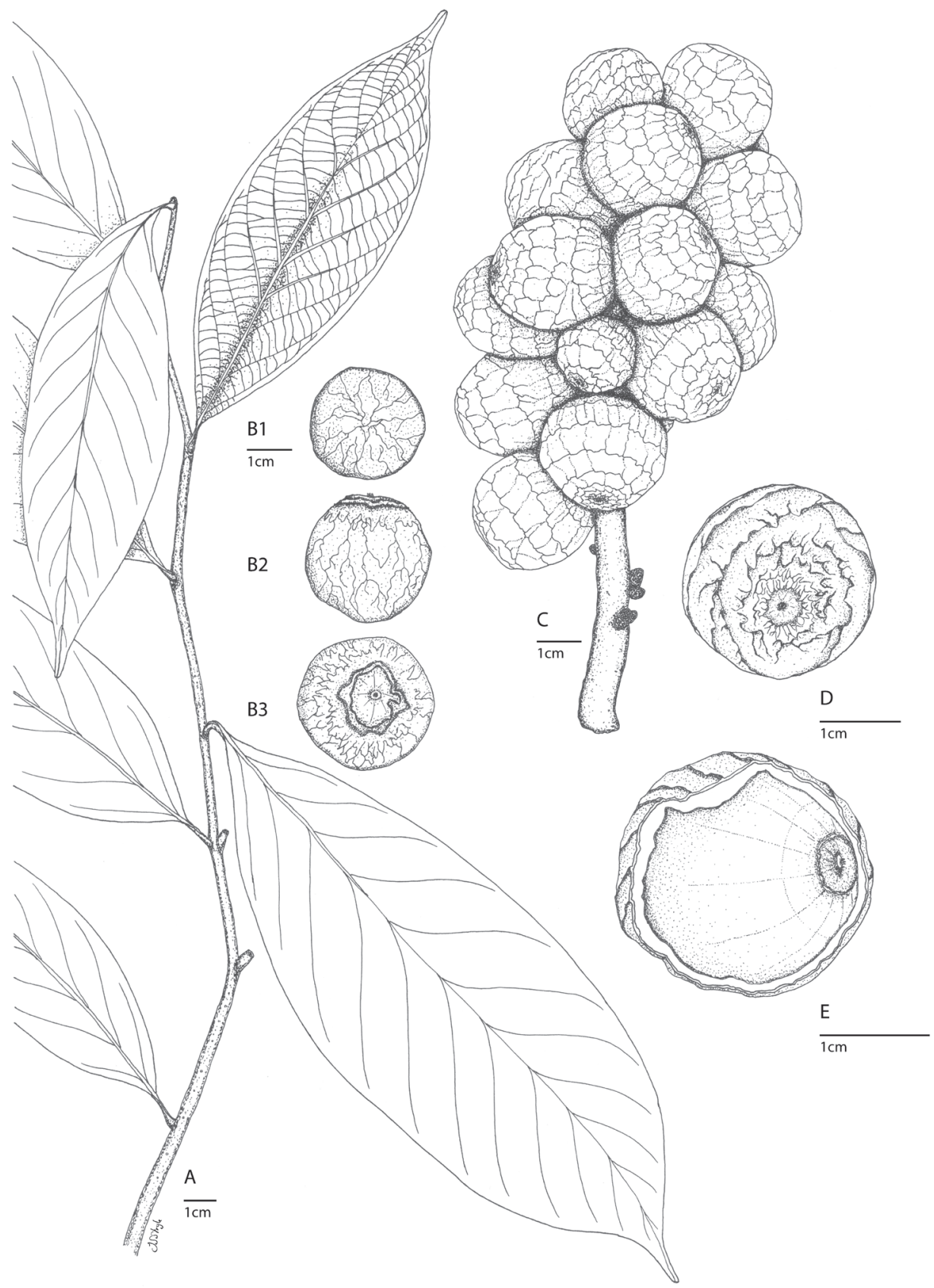

Figure I. Lithocarpus orbicarpus Strijk, sp. nov. Chamchumroon et al. 5823 (BKF). Technical illustration. A Habit B Detail of glabrous young fruit with ridges and apical pore C Detail of interior of young fruit, showing nearly complete fruit scar, covered umbo and 'pitted pattern' on the nut surface D Infructescence with ripe fruits showing highly irregular scaly patterns on the fruit exterior $\mathbf{E}$ Details of seed, from left to right: bottom view, side view, top view. Note venation and crevice pattern on surface of fruit, and cover of the umbo section. All drawings by J.S. Strijk. 
Ecology. This species grows in dense hillside forest at an elevation of around $450 \mathrm{~m}$. Vernacular name. Unknown.

Etymology. Lithocarpus orbicarpus is named after its unique orbicular acorns, arranged densely clustered on an erect spike, of which the cup almost completely encloses the nut (except for a tiny apical pore). The exterior of the cup is covered with a dense pattern of ridges, transforming with age into horizontal and vertical lines with irregularly placed scales. Apart for a tiny portion of the umbo which is covered with vestigial exocarp, the exterior surface of the nut is completely covered by scar. Although the cupule nearly completely covers the nut, the latter is free and not fused to the wall of the cupule - a condition which occurs throughout the genus (Cannon 2001; Cannon and Manos 2001). Upon drying, the shrinking of the cotyledons inside the nut causes the whole infructescence to make a rattling sound when shaken.

Discussion. Thailand has a total of 121 species, 2 subspecies and 2 varieties of Fagaceae in four genera indigenous to the country. Of these, nine species (Castanopsis: 4; Quercus: 1; Lithocarpus: 4) and 1 subspecies (Quercus: 1) are national endemics (Bunpha et al. 2011; Phengklai 2008). Three of the endemic Lithocarpus species (including L. orbicarpus) are restricted to small ranges in the peninsular region. Of the 58 Lithocarpus known to occur in Thailand (including this newly described species), 43 species (74\%) can be found in the Peninsular floristic province making it the most diverse floristic region (in terms of Lithocarpus species) followed by the North (25 species $-43 \%)$. While the Northern (and North-eastern) floristic province is characterized by species that reach high elevation habitat ( $>75 \%$ can be found between $1200-2500 \mathrm{~m}$ ), the Peninsular complement includes species that are restricted to lower elevations (21 species restricted $<500 \mathrm{~m}$ asl). With two exceptions (L. falconeri (Kurz) Rehder and L. erythrocarpus (Ridl.) A.Camus), none of these species are shared with the North (or North-east). In contrast, four of the Peninsular lowland species (L. lucidus (Roxb.) Rehder; L. maingayi (Benth.) Rehder; L. reinwardtii (Korth.) A.Camus; L. tubulosus (Hickel \& A.Camus) A.Camus) are shared with the South-eastern floristic province, in addition to L. elephantum (Hance) A.Camus and L. pierrei (Hickel \& A.Camus) A.Camus, which can only be found in the South-eastern region.

Lithocarpus in Thailand can be further characterized based on their acorn (cupule+nut) properties. The open- or semi-open type, in which the cupule shape ranges from saucer shaped-flat to covering up to $4 / 5$ th of the nut is present in 37 species (64\%), while the remaining 18 species have cupules that entirely cover the nut, in most cases leaving a tiny portion of the umbo uncovered. With one exception (L. truncates (King ex Hook.f.) Rehder), all closed-type species occur in the Peninsula, and eight are restricted to it (two shared with the Southeast). L. orbicarpus resembles species in this group, with its indehiscent and near-closed cupules, restricted geographical distribution and presence in lower elevation habitat, but is clearly distinct from them based on the structure and shape of the fruit, the infructescence and the properties of the nut.

During our field survey, we encountered and collected additional Fagaceae species, e.g. Lithocarpus reinwardtii (Korth.) A.Camus (Burma, Cambodia, Malaysia, Indonesia), L. sundaicus (Blume) Rehder (Malaysia, Indonesia, Brunei), L. cantleyanus (King ex Hook.f.) 

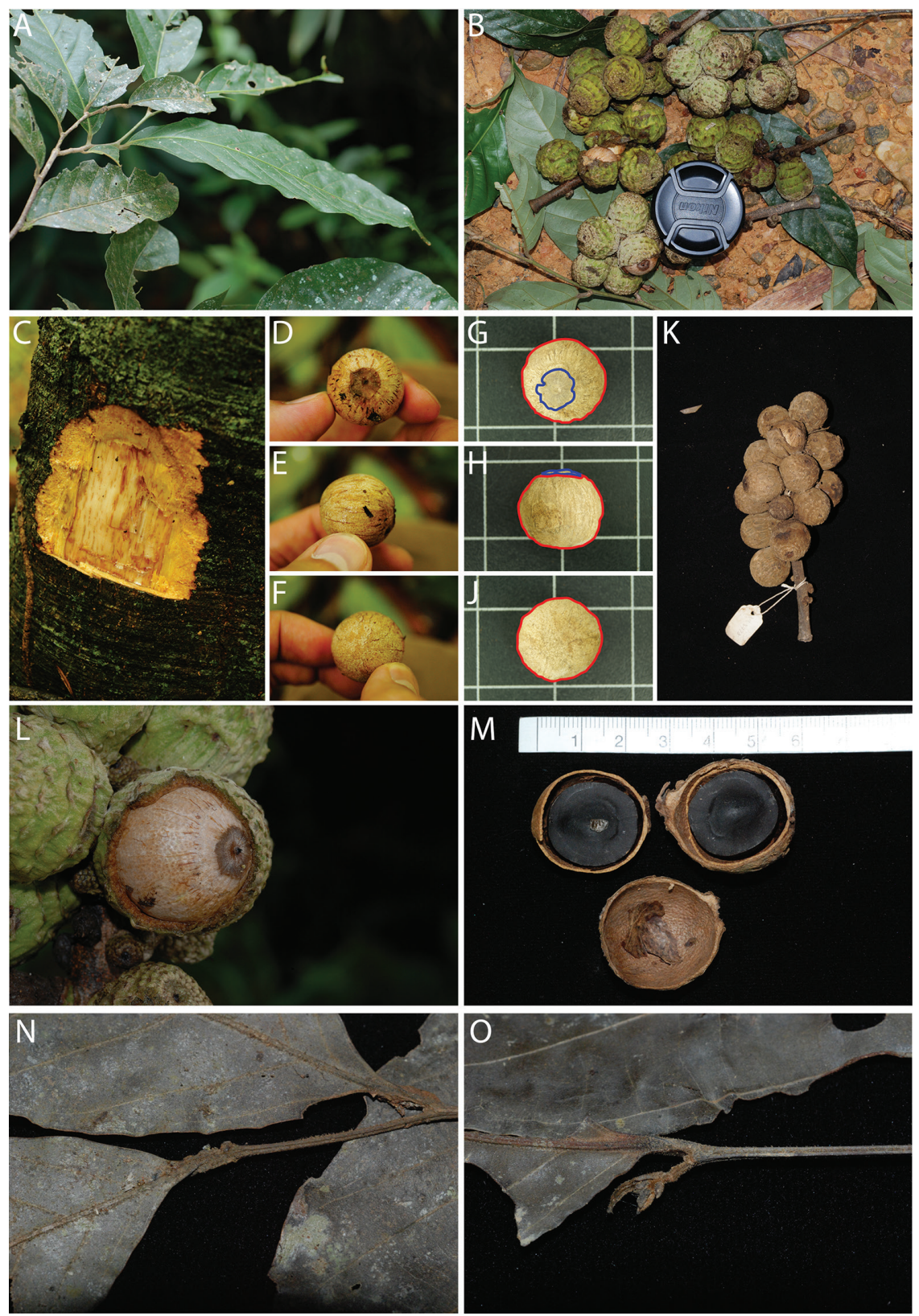

Figure 2. Lithocarpus orbicarpus Strijk, sp. nov. Chamchumroon et al. 5823 (BKF). Pictures from field collection. A Branch with leaves B Young infructescences C Bark and sapwood D Fresh fruit - top view E Fresh fruit - side view $\mathbf{F}$ Fresh fruit - bottom view $\mathbf{G}$ Dried fruit - top view $\mathbf{H}$ Dried fruit - side view J Dried fruit - bottom view (G-J: blue lines demarcate vestigial exocarp; red lines demarcate scar area (receptacle tissue)) $\mathbf{K}$ Dried infructescence $\mathbf{L}$ Young acorn, opened up to show dotted pattern of small depressions and surface structure of the umbo $\mathbf{M}$ Cross-section of fried nut, showing seed coat and black cotyledons $\mathbf{N}$ Terminal leaf, twig and very small terminal bud, showing grey indumentum $\mathbf{O}$ Young emerging leaf with soft grey indumentum. All pictures by S. Sirimongkol and J. S. Strijk. 
Rehder (Burma, Malaysia, Singapore) and several, as of yet, unidentified collections. Additional species encountered in previous surveys in the wildlife sanctuary are: Castanopsis javanica (Blume) A.DC. (Vietnam, Malaysia, Singapore, Indonesia); Castanopsis nephelioides King ex Hook. f. (Malaysia, Singapore); Castanopsis purpurea Barnett (Thailand (endemic)); Castanopsis wallichii King ex Hook. f. (Malaysia, Singapore, Indonesia); Castanopsis inermis (Lindl.) Benth. \& Hook. f. (Burma, Malaysia, Singapore, Indonesia, Philippines); Lithocarpus bennettii (Miq.) Rehder (Malaysia, Singapore, Indonesia); Lithocarpus clementianus (King) A.Camus (Malaysia, Indonesia); Lithocarpus eucalyptifolia (Hickel et A.Camus) A.Camus (Burma, Vietnam, Cambodia); Lithocarpus falconeri (Kurz) Rehder (Burma, Malaysia); Lithocarpus garrettianus (Craib) A.Camus (China, Burma, Laos, Vietnam); Lithocarpus lucidus (Roxb.) Rehder (India, Malaysia, Singapore, Indonesia, Brunei); Lithocarpus macphailii (Henders.) Barnett (Malaysia, Indonesia); Lithocarpus wrayi (King) A.Camus (Vietnam, Malaysia, Indonesia) and Quercus oidocarpa Korth. (Burma, Vietnam, Malaysia, Indonesia). Out of these 17 species, at least 14 have a geographic distribution that is primarily or completely located in the Sundaland biogeographic region. Conversely, only three species have a distribution that is mostly or entirely contained within the Indochinese biogeographic region. Despite the paucity of detailed biological records on this remote area, the distributional data shows us that the Fagaceae flora in Ton Pariwat Wildlife Sanctuary is distinctly Sundaic in composition, and differs substantially from forests in the more northern Indochinese region. This is in fact not surprising, as the Ton Pariwat Wildlife Sanctuary is located near the southern edge of one of the world's major phytogeographic and zoogeographic transition zones: the $-500 \mathrm{~km}$ stretch between the biogeographically distinct and well-known Isthmus of $\mathrm{Kra}$ - the narrowest part of the connection between mainland Southeast Asia and the Malay Peninsula $\left(10^{\circ} 30^{\prime} \mathrm{N}\right)$ - and the line between Kangar (Malaysia) - 6.51'N, and Pattani (Thailand) 6 ${ }^{\circ} 87^{\prime} \mathrm{N}$. Within this relatively short distance, an abrupt and major shift takes place from northern Indochinese flora and fauna, to those distinct for the southern Sundaland region (Hughes et al. 2003; Meijaard 2009; Parnell 2013; Van Steenis 1950; Woodruff 2003; Woodruff and Turner 2009).

When looking at the Fagaceae flora in the wider region, some properties of L. orbicarpus resemble species in Peninsular Malaysia, such as Castanopsis nephelioides King ex Hook.f., but can easily be distinguished from species within Castanopsis (D.Don) Spach, based on the presence of bark ridges that penetrate the sapwood, the nut which is not fused to the cup and the orbicular shape of the fruit. Congeneric species from the Indo-Chinese zone that share some characters with $L$. orbicarpus are $L$. rouletii (Hickel \& A.Camus) A.Camus (but fruit with basal scar, flattened, dehiscent; South Vietnam); L. pachycarpus (Hickel \& A.Camus) A.Camus (but leaves with yellow indumentum, cupules pear-shaped, acorns not orbicular; Vietnam-Laos); L. kontumensis A.Camus (but cupules truncate, higher than acorn, cupules sometimes fused; Vietnam-Laos); L. lepidocarpus (Hayata) Hayata (but cupules truncate, sometimes fused, fruit not orbicular; central and south Taiwan); and L. laoticus (Hickel \& A.Camus) A.Camus (but cupule ovoid, high elevation habitat (Tibet, south and central China, Vietnam) (Wu et al. 1999). Within Thailand, L. orbicarpus is unique in its combination of properties, and we outline some of the defining differences with Thai species in Table 1 below. 
Table I. Morphological differences between L. orbicarpus and other Thai species of Fagaceae.

\begin{tabular}{|c|c|c|c|c|}
\hline Characters & L. orbicarpus Strijk & $\begin{array}{c}\text { L. encleisocarpus } \\
\text { A.Camus }\end{array}$ & $\begin{array}{l}\text { L. wrayi (King) } \\
\text { A.Camus }\end{array}$ & $\begin{array}{c}\text { C. nephelioides King } \\
\text { ex Hook.f. }\end{array}$ \\
\hline 1. Nut wall & Free from the cup & Free from the cup & Free from the cup & Fused to the cup \\
\hline $\begin{array}{l}\text { 2. Cupule } \\
\text { enclosure }\end{array}$ & $\begin{array}{l}\text { Almost complete, but small } \\
\text { apical pore showing flat umbo } \\
\text { remains }(\leq 5 \%) \text {. Indehiscent. }\end{array}$ & $\begin{array}{c}\text { Almost complete, } \\
\text { but raised umbo free } \\
( \pm 5-10 \%) \text {. Easily } \\
\text { dehiscent in irregular } \\
\text { parts. } \\
\end{array}$ & $\begin{array}{c}\text { Almost complete, but } \\
\text { raised umbo free }( \pm 5- \\
15 \%) \text {. Indehiscent. }\end{array}$ & $\begin{array}{l}\text { Enclosure complete. } \\
\text { Indehiscent. }\end{array}$ \\
\hline 3. Nut shape & Orbicular. & Ovoid to globose. & Broadly conical. & $\begin{array}{c}\text { Ovoid, usually } \\
\text { depressed to one } \\
\text { longitudinal side. }\end{array}$ \\
\hline $\begin{array}{l}\text { 4. Cup } \\
\text { surface }\end{array}$ & $\begin{array}{l}\text { Spines absent. Small, flattened } \\
\text { scales present. Irregularly } \\
\text { intersecting lines present. } \\
\text { Old acorns pubescent with } \\
\text { short (occasionally long), } \\
\text { greyish-yellow indumentum. }\end{array}$ & $\begin{array}{c}\text { Spines and scales } \\
\text { absent. Wall smooth, } \\
\text { densely greenish- } \\
\text { brown hairy. }\end{array}$ & $\begin{array}{c}\text { Alternate pseudo- } \\
\text { spines and free scales } \\
\text { present; pseudo-spines } \\
\text { incurved or erect. }\end{array}$ & $\begin{array}{l}\text { Sparsely covered } \\
\text { with short, woody } \\
\text { spines, } 2-3 \text { branched } \\
\text { reclining and } \\
\text { decurved. }\end{array}$ \\
\hline $\begin{array}{l}\text { 5. Acorn } \\
\text { shape }\end{array}$ & $\begin{array}{l}\text { Orbicular, symmetric; young } \\
\text { fruits occasionally slightly } \\
\text { skewered in young and dense } \\
\text { infructescences }\end{array}$ & Ovoid or turbinate. & Broadly ovoid. & $\begin{array}{l}\text { Obovoid, always } \\
\text { asymmetric, usually } \\
\text { flattened adaxially. }\end{array}$ \\
\hline $\begin{array}{l}\text { 6. Leaf } \\
\text { margin }\end{array}$ & Entire throughout. & Entire throughout. & Entire throughout. & $\begin{array}{c}\text { Entire or serrate in the } \\
\text { upper half. }\end{array}$ \\
\hline \begin{tabular}{c|}
7. Scar \\
position, \\
shape and size
\end{tabular} & $\begin{array}{l}\text { Orbicular, covering } \geq 95 \% \\
\text { of the fruit, from the base } \\
\text { upward. }\end{array}$ & \begin{tabular}{|c|} 
Basal, slightly \\
concave, ca. $1 \mathrm{~cm}$ in \\
diameter.
\end{tabular} & $\begin{array}{c}\text { Basal, concave, ca. } 1.5 \\
\mathrm{~cm} \text { in diameter. }\end{array}$ & - (nut fused to wall). \\
\hline $\begin{array}{c}\text { 8. Nut } \\
\text { indumentum }\end{array}$ & Glabrous. & Greyish pubescent. & $\begin{array}{l}\text { Sparsely sericeous } \\
\text { then dull brown. }\end{array}$ & - (nut fused to wall). \\
\hline
\end{tabular}

This species is endemic to Thailand and is currently only known from one location in Ton Pariwat Wildlife Sanctuary. The sanctuary covers a region of low-lying forested mountains with a total area of approximately 100,000 ha at the southern end of the Phuket mountain range. As such it is an integrated part of the Southern Forest Complex of Thailand. The sanctuary is popular for its rich bird- and wildlife (e.g. Blue-banded Kingfisher (Alcedo euryzona Temminck, Alcedinidae) and Whitehanded Gibbons (Hylobates lar L., Hylobatidae) as well as rare flora, such as Rafflesia kerrii Meijer (Rafflesiaceae). Its unique species composition, high diversity and relatively intact forest structure underscore the importance of strengthening ongoing and future conservation measures at Ton Pariwat Wildlife Sanctuary, as a key element of wider conservation efforts in southern Thailand.

\section{Updated key for the species of Lithocarpus occurring in Thailand}

Following the treatment of Fagaceae for the Flora of Thailand (Phengklai 2008), no further updates have been published. In the updated key we include here, we incorporate the identification of $L$. orbicarpus and add several additional corrections. 


\section{Key to the thai species of Lithocarpus}

(based on vegetative characters and acorns)

1 Outer surface of cupules with annular or lamellate markings or markings lacking

2 Cupules without lamellae, chartaceous or subcoriaceous, enclosing nearly all of the nut, more or less dehiscent when mature

3 Cupules weakly dehiscent from the apex, cupule surface distinctly undulate with vertical and horizontal lines

$4 \quad$ Cupule urn-shaped

5 Cupule base broadly conical, much broader than apex, skin distinct with many vertical filiform lines or without. Nut conical

5. L. blumeanus

5 Cupule base obconic, much narrow than apex, surface distinct with 3-4 horizontal filiform lines. Nut obconical

33. L. maingayi

$4 \quad$ Cupule top or globe shaped

Cupule top-shaped, enclosing 4/5 of nut, surface with 2-6 distinct horizontal, filiform lines.

30. L. macphailii

Cupule globe-shaped, enclosing nut completely, except for a tiny section at the apex, surface with distinct irregularly placed scales along 5-9 horizontal and vertical lines

36. L. orbicarpus

3 Cupules readily dehiscent into irregular parts from the top, surface with 2-5 filiform, undulate, horizontal lines

$7 \quad$ Cupules with 2 or 3 such lines

$7 \quad$ Cupules with 4 or 5 such lines

18. L. encleisocarpus

Cupules with distinct lamellae, coriaceous, enclosing a variable amount of the nut, indehiscent

8 Cupule enclosing not less than $1 / 2$ of the nut

9 Cupule enclosing about $1 / 2$ of the nut

10 Nuts ovoid to conical at apex, scar shallowly concave or flattened

10 Nuts subhemispheric or depressed at apex, scar deeply concave

24. L. gracilis

8. L. clementianus

9 Cupule enclosing not less than 3/4 of the nut

11 Cupules obconic, enclosing nut almost completely except around the umbonate apex

12 Nut longer than broad, ca. 1 by $0.7 \mathrm{~cm}$

26. L. hendersonianus

12 Nut shorter than broad, $1-2.7$ by $2-3 \mathrm{~cm}$ 32. L. magnificus

11 Cupules saucer-shaped, enclosing ca. 3/4 of the nut.

1. L. aggregatus

8 Cupule enclosing not more than $1 / 4$ of the nut

13 Nuts hemispheric or depressed on both sides

14 Cupule enclosing $1 / 5$ to $1 / 4$ of the nut......

39. L. platycarpus

14 Cupule enclosed only the base of the nut 
15 Acorns sessile. Scar deeply concave. 15. L. eichleri

13 Nuts conical to broadly ovoid, or with a dome-shaped apex

16 Cupule enclosing only the base of the nut

17 Acorns sessile. Leaves oblanceolate 29. L. lucidus Acorns with fruit-stalk up to $0.5 \mathrm{~cm}$ long. Leaves oblong.

43. L. reinwardtii Cupule enclosing ca. 1/4 of the nut Nut with one horizontal ring around equator. Leaves ensiform to linearlanceolate

19 Nut ovoid or conical. Cupules cup or saucer-shaped. Leaves ovate or ovateoblong, apex caudate.

3. L. bancanus

19 Nut broadly ovoid. Cupules slightly obconical to saucer-shaped. Leaves narrowly elliptical

41. L. rassa

Outer surface of cupules with alternate lamellae (resembling fish scales) or pseudospines

20 Mature cupules of one infructescence more or less fused together

21 Acorns broader than long, depressed both on top and at base. Cupules sauceror cupshaped or obconic, some hardly distinct from each other through fusion Infructescences with densely arranged cupules

24 Nut flattened or apiculate at apex, to $2.2 \mathrm{~cm}$ diam. Leaves cuneate at base ...

16. L. elegans

Nut retuse at apex, not less than $3 \mathrm{~cm}$ diam. Leaves auriculate at base

2. L. auriculatus

22 Infructescences with spaces between cupules

25 Rachis of infructescence always with sub-branches. Acorns stalked

Rachis of infructescence without sub-branches

Acorns longer than broad, conical, ovoid or turbinate. Cupules cup-shaped or cylindric

Rachis of infructescence always with sub-branches. Acorns stalked, nuts shining Acorn up to $1 \mathrm{~cm}$ high. Rachis up to $4 \mathrm{~mm}$ in diam. Acorn not less than $1 \mathrm{~cm}$ high (to $2.5 \mathrm{~cm}$ ). Rachis not less than $4 \mathrm{~mm}$ in diam

27 Rachis of infructescence without sub-branches. Acorns sessile, nuts more or less shining

29 Twigs glabrous or sparsely pubescent then glabrous

30 Cupules cup-shaped, enclosing up to $1 / 2$ of the nut 
30 Cupules turbinate, enclosing the whole nut, open only around umbo

53. L. truncatus

29 Twigs ferruginous or tomentose

31 Leaves glabrous except along midrib. Cupules enclosing up to $1 / 3$ of the nut 25. L. harmandianus

31 Leaves densely tomentose especially on lower surface. Cupules enclosing $1 / 2$ of the nut. 27. L. lindleyanus

20 Mature cupules of one infructescence, free, not fused

32 Acorn longer than broad, conical, ovoid or obconical. Cupules cup- or saucer-shaped or obconic

33 Cupules enclosing nut completely or $2 / 3$ of the nut

34 Cupules enclosing ca. $2 / 3$ of the nut

35 Cupules slightly obconical-shaped, nuts hairy at style apex (if persistent)......

Cupules cup or saucer-shaped 45. L. rufescens

34 Cupules enclosing nut completely, or up to the apex of the nut 16. L. elegans Cupules dehiscent, obconic or ovoid

7 Cupules obovoid, sessile, surface with dense, long and narrow recurved pseudospines

42. L. recurvatus

Cupules enclosing up to $1 / 2$ of the nut

Cupules ovoid, fruit stalk 2-3 mm long, surface finely ornamented with thin, triangular lamellae throughout.

35. L. neo-robinsonii Cupules indehiscent, ovoid, surface clothed with dense, triangular lamellae Infructescences up to $18 \mathrm{~cm}$ long. Leaves up to $16 \mathrm{~cm}$ long..... 9. L. craibianus Infructescences not less than $20 \mathrm{~cm}$ long. Leaves not less than $20 \mathrm{~cm}$ long ...

19. L. erythrocarpus Acorns stalked

Cupules slightly obconic. Leaves ovate, ovate-oblong or obovate

48. L. sootepensis

Cupules cup-shaped or saucer-shaped

Cupules cup-shaped. Leaves lanceolate to lanceolate oblong

47. L. siamensis Cupules saucer-shaped to flattened. Leaves oblong to oblong-lanceolate.

10. L. curtissii

Acorns sessile

Acorns (mature) not less than 3.5 by $2.2 \mathrm{~cm}$

Cupule lamellae bearing pseudo-spined reflexed towards the base. Leaves acute to obtuse at apex....

46. L. scortechinii

Lamellae curved towards the cupule apex. Leaves acuminate at apex

Acorns (mature) up to 3 by $2.2 \mathrm{~cm}$

44 Infructescence with acorns in clusters, but not fused 
45 Nuts strongly apically depressed, occasionally conic. Leaves not curved

44 Infructescence with acorns solitary, with spaces between them

46 Cupules saucer or cup-shaped, limb recurved. Leaves not less than $12 \mathrm{~cm}$ long 21. L. falconeri

46 Cupules obconical, limb not recurved. Leaves up to $11 \mathrm{~cm}$ long

4. L. bennettii

32 Acorns broader than long, hemisphaeric-depressed

47 Cupules enclosing the nut completely or up to the apex of the nut

48 Cupules more or less up to the apex of the nut, lamellae with erect or reflexed pseudospines which are not fused

49 Pseudo-spines erect or spreading. Leaves oblanceolate. Scar nearly $1 / 2$ of the nut.....

14. L. echinops

49 Pseudo-spines reflexed. Leaves oblong or oblanceolate

50 Infructescence with acorns packed close together, but not fused. Leaves slightly cuneate at base.....

23. L. garrettianus

50 Infructescence with acorns solitary, with spaces between them. Leaves obtuse at base.

54. L. tubulosus

Cupules enclosing the nut completely, except the umbo

Lamellae pointed, with narrowly pseudospines. Infructescence with acorns packed close together, but not fused

57. L. wrayi

Lamellae flattened and imbricate. Infructescence with acorns solitary, with spaces between them

2 Lamellae fused on lower half, the upper half free and adaxially curved

22. L. fenestratus

52 Lamentas fused almost to apex, only a short free lobe adaxially curved.

52. L. trachycarpus

Cupules enclosing up to $1 / 2$ of the nut

Acorns stalked, cupules enclosing only base of the nut

Stalk up to $1 \mathrm{~cm}$ long. Leaves glaucous on lower surface, petiole up to $1 \mathrm{~cm}$ long

49. L. sundaicus

Stalk not less than $1 \mathrm{~cm}$ long. Leaves pale on lower surface, not glaucous, petiole not less than $1 \mathrm{~cm}$ long.

31. L. magneinii

53 Acorns sessile, cupules enclosing up to $1 / 2$ of the nut

55 Acorns not less than 2 by $2.5 \mathrm{~cm}$

56 Cupules slightly obconical. Leaves oblong, acute to caudate at apex, margin not revolute, petiole not less than $1 \mathrm{~cm}$. 11. L. cyclophorus Cupules saucer-shaped. Leaves obovate, obtuse at apex, margin revolute, petiole up to $0.6 \mathrm{~cm}$ long 44. L. revolutus

$57 \quad$ Nuts convex at the apex

58 Cupules saucer-shaped to flattened and discoid. Leaves not whorled

59 Lamellae usually fused throughout. Leaves up to $15 \mathrm{~cm}$ long...38. L. pierrei 
59 Lamellae fused at base only, apices free. Leaves not less than $18 \mathrm{~cm}$ long 17. L. elephantum

58 Cupules cup-shaped. Leaves usually whorled at the twig tips... 58. L. xylocarpus 57 Nuts flattened at the apex. Cupule cup-shaped, enclosing $1 / 5$ to $1 / 2$ of the nut. Leaves with unequal sides, usually curved to one side

60 Leaves oblong, elliptic oblong, not less than 10 by $3.5 \mathrm{~cm}$, with 14-20 pairs of lateral nerves

55. L. vestitus

\section{Acknowledgements}

We are grateful to staff of the Ton Pariwat Wildlife Sanctuary for assistance in the field. We thank R. Pooma and staff of the Forest Herbarium (BKF) for access to collections. Finally, we would like to acknowledge S. Suddee and A. Sinbumroong for advice in identification and the preparation of this manuscript. The first author was supported by a Postdoctoral Research Fellowship of the Chinese Academy of Sciences (2011-2014).

\section{References}

Barnett EC (1940) A survey of the genus Quercus and related genera of the Fagaceae in Asia with a more detailed account of the Siamese species of these genera and notes on the use of leaf anatomy in taxonomy. D.Sc. Thesis, University of Aberdeen, Scotland.

Bunpha K, Masuthon S, Phengklai C (2011) Quercus thorelii Hickel \& A. Camus (Fagaceae), a new record for Thailand. Thai Forest Bulletin (Botany) 39: 206-209. http://web3.dnp. go.th/botany/pdf/TFB/TFB9/TFB39_12_Quercus.pdf

Camus A (1948) Les chênes. Monographie des genres Quercus et Lithocarpus. Atlas, vol.3. Encyclopédie Économique de Sylviculture 7: 152-165.

Camus A (1952-54) Les chênes. Monographie des genres Quercus et Lithocarpus 8. 511-1196.

Cannon CH (2001) Morphological and molecular diversity in Lithocarpus (Fagaceae) of Mount Kinabalu. Sabah Parks Nature Journal 4: 45-69. doi: 10.1080/106351501753462849

Cannon CH, Manos PS (2001) Combining and comparing morphometric shape descriptors with a molecular phylogeny: the case of fruit type evolution in Bornean Lithocarpus (Fagaceae). Systematic Biology 50(6): 860-880.

Hughes JB, Round PD, Woodruff DS (2003) The Indochinese-Sundaic faunal transition at the Isthmus of Kra: an analysis of resident forest bird species distributions. Journal of Biogeography, 30(4): 569-580. doi: 10.1046/j.1365-2699.2003.00847.x

Manos Paul S, Cannon CH, Oh S-H (2008) Phylogenetic relationships and taxonomic status of the paleoendemic Fagaceae of western North America: recognition of a new genus, Notholithocarpus. Madrono 55.3: 181-190. doi: 10.3120/0024-9637-55.3.181

Meijaard E (2009) Solving mammalian riddles along the Indochinese-Sundaic zoogeographic transition: new insights from mammalian biogeography. Journal of Biogeography, 36(5):801-802. doi: 10.1111/j.1365-2699.2009.02124.x 
Parnell J (2013) The biogeography of the Isthmus of Kra: a review. Nordic Journal of Botany 31: 001-015.

Phengklai C (2004) Three new species and a new variety of Fagaceae from Thailand. Thai Forest Bulletin (Botany) 32: 115-122. http://web3.dnp.go.th/botany/pdf/TFB/TFB32/ TFB32_9Fagaceae.pdf

Phengklai C (2008) Fagaceae. Vol.9 (3). In: Santisuk T, Larsen K, Nielsen I, Chayamarit K, Phengkhlai C, Pedersen H, Parnell J, Middleton D, Newman M, Simpson DA, van Welzen PC, Hul S, Kato M (Eds) Flora of Thailand. The Forest Herbarium, National Parks, Wildlife and Conservation Department, Bangkok.

Soepadmo E (1972) Fagaceae. Flora Malesiana Series I, Volume 7 (2). Rijksherbarium /Hortus Botanicus, Leiden University, Leiden, The Netherlands.

Van Steenis C (1950) The delimitation of Malaysia and its main plant geographical divisions. Flora Malesiana Series 1.

Woodruff DS (2003) The location of the Indochinese-Sundaic biogeographic transition in plants and birds. Natural History Bulletin of the Siam Society 51: 97-108.

Woodruff DS, Turner LM (2009) The Indochinese-Sundaic zoogeographic transition: a description and analysis of terrestrial mammal species distributions. Journal of Biogeography, 36(5): 803-821. doi: 10.1111/j.1365-2699.2008.02071.x

Wu CY, Raven PH, Hong DY (1999) (Eds) Flora of China (Cycadaceae through Fagaceae) Vol. 4, Beijing \& St. Louis, Science Press \& Missouri Botanical Garden Press. http://flora. huh.harvard.edu/china/mss/volume04/FAGACEAE.published.pdf 